\title{
Stellate Reticulum
}

National Cancer Institute

\section{Source}

National Cancer Institute. Stellate Reticulum. NCI Thesaurus. Code C33613.

A central core of loosely arrang ed stellate cells located between the outer and inner epithelial enamel of the developing tooth. 